\title{
Integrating Theory A and Six Thinking Hats Technique for Improved Organizational Performance
}

\author{
P. S. Aithal \& Suresh Kumar P. M. \\ Srinivas Institute of Management Studies, Srinivas University, Mangalore - 575 001, INDIA. \\ E-Mail: psaithal@gmail.com
}

Type of the Paper: Research Paper.

Type of Review: Peer Reviewed.

Indexed In: OpenAIRE.

DOI: http://dx.doi.org/10.5281/zenodo.1045417.

Google Scholar Citation: IJAEML

\section{How to Cite this Paper:}

Aithal, P. S., \& Suresh Kumar, P. M. (2017). Integrating Theory A and Six Thinking Hats Technique for Improved Organizational Performance. International Journal of Applied Engineering and Management Letters (IJAEML), 1(2), 66-77.

DOI: http://dx.doi.org/10.5281/zenodo.1045417.

International Journal of Applied Engineering and Management Letters (IJAEML)

A Refereed International Journal of Srinivas University, India.

(C) With Authors.

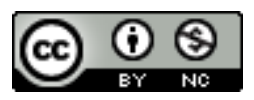

This work is licensed under a Creative Commons Attribution-Non Commercial 4.0 International License subject to proper citation to the publication source of the work.

Disclaimer: The scholarly papers as reviewed and published by the Srinivas Publications (S.P.), India are the views and opinions of their respective authors and are not the views or opinions of the S.P. The S.P. disclaims of any harm or loss caused due to the published content to any party. 


\title{
Integrating Theory A and Six Thinking Hats Technique for Improved Organizational Performance
}

\author{
P. S. Aithal \& Suresh Kumar P. M. \\ Srinivas Institute of Management Studies, Srinivas University, Mangalore - 575 001, INDIA. \\ E-Mail: psaithal@gmail.com
}

\begin{abstract}
Various models are used in developing strategies to improve people's performance in organizations. Such for example, are theory X, theory Y, and theory A. All these in common are based on presumptions about the human behaviour at work. Theory $\mathrm{X}$ and $\mathrm{Y}$ are opposing each other in predicting human nature. Theory A (Theory of Accountability) focuses on innate human potential, inherent urge for creativity, self-expression, and contribution to the organization as motivators. This is a winning strategy by collectively setting in motion a process of shared goals, divided responsibility, mutual inspiration and shared output. So much so managers have to transform average employee to real performers using role models and self-exploration. Accountability is assumed by both individuals and teams to ensure success in given task. The functional elements of Accountability Theory are Planning, Target setting, Motivation, Work Strategies, Responsibility, Role model, Monitoring \& Guiding, and Accountability. This is indicative of a series of processes starting from Institutional assessment to problem identification and joint policy formulation; shared understanding through communication and action planning; Adoption of the idea and increased performance; Empowerment, support and teamwork; Commitment, consistency, and target fulfilment; Acknowledging example and willingness to improve; Joint review, self-appraisal, and confirmation of accomplishment; and Contribution through commitment and creativity. In all these stages lateral thinking through Six thinking hats opens up possibilities for objective and quantitative thinking, emotional thinking, negative pessimistic thinking, cautious optimistic thinking, creative innovative thinking and managerial thinking. In this paper, we have discussed how Theory A can be integrated with different types of thinking styles in any organization to improve its performance using six thinking hats model of lateral thinking.
\end{abstract}

Keywords: Theory A, Six Thinking Hats Technique, Organizational Performance.

\section{INTRODUCTION :}

Maintaining sustainable profit is a common objective all business organizations. One of the methods to achieve it is by improving the organizational performance through enhancing employee productivity. Many studies were conducted on organizational performance and employee efficiency, through various models which include Organizational creativity theory [1], Organizational culture Model [2], Performance management model [3], and TQM \&organisational performance model [4]. ASTD Models for Human Performance Improvement [5], Emotional intelligence models [6-10], Spiritual intelligence models [11-12], Competency Mapping models [13-15], HRD Model [16], Selfefficacy and Learning Orientation model [17], Social Skills model [18], Innovation model [19], Employee engagement model [20], IPS-EQ model [21], Theory X and Theory Y [22] Theory Z [23]. The latest among this is Theory of Accountability (Theory A) [24-29] which focuses on innate human potential, inherent urge for creativity, self-expression, and contribution to the organization as motivators. 


\section{THEORY OF ACCOUNTABILITY :}

The recently developed Organizational Performance Theory for $21^{\text {st }}$ Century called Theory of Accountability (Theory A) focus on urge for creativity as the cornerstone of all performance. Fostering the inherent urge for creativity will bring out the best in the form of sustained accountability [24-29]. According to Theory A or Theory of Accountability, the whole organization prepares for a collective endeavour, joint identification of need, joint policy formulation, ensuring responsibility, developing strategy and displaying creativity in achieving it. Accountability should be fixed to both individuals and teams in order to ensure success in given task. The functional elements of Accountability Theory (Theory A) are : (1) Planning (2) Target setting (3) Motivation (4) Work Strategies (5) Responsibility (6) Role model (7) Monitoring \& Guiding and (8) Accountability. The sub functions under these are a series of processes starting from (1) Institutional assessment to problem identification and joint policy formulation, (2) Shared understanding through communication and action planning, (3) Adoption of the idea and increased performance, (4) Empowerment, support and teamwork, (5) Commitment, consistency, and target fulfilment, (6) Acknowledging example and willingness to improve, (7) Joint review, self-appraisal, and confirmation of accomplishment, and (8) Contribution through commitment and creativity, under each of the steps mentioned above.

\section{SIX THINKING HATS TECHNIQUE AS LATERAL THINKING TOOL :}

Six thinking hats supports lateral thinking possibilities during problem-solving sessions. Out of the various lateral thinking techniques used in analysing a situation, Six Thinking Hats technique finds importance due to its ability to identify the attributes of a situation from six different perspectives. In six thinking hats technique, Dr. Edward de Bono outlines different thinking styles required by an individual while analysing a given problem in a systematic way. The technique represents the different thinking styles used in an effective problem-solving procedure with six different colour hats [30]. This approach guides the individual to use a particular thinking style represented by particular colour hat. Accordingly, the WHITE hat represents neutral judgements based on facts and figures, the RED hat represents humanistic thinking filled with emotions and feelings, the YELLOW hat represents positive aspects of the situation, the BLACK hat represents pessimistic or negative thinking based on comments, criticism, caution \& carefulness, while GREEN hat use innovative and creative thinking, and the BLUE hat represents managerial thinking based on planning, organizing and controlling [31-36]. The following is the discussion on integrating the six different types of thinking in the eight stages of Theory of Accountability.

\section{VARIOUS STAGES OF THEORY A :}

\section{(1) Planning:}

The vision, mission, and objectives of an organization should be clear on the organizational contribution towards development. Being the first element of the theory of Accountability, planning finds a very important role in transforming a mediocre organization into a brisk activity centre through an optimized contribution from employees. By jointly setting the objectives of the organization, an organization can encourage its employees to think innovatively. Through planning organizational and team objectives the organization can recruit and train its members to be innovative with a passion for creativity. The organization can develop its planning strategy as the blue ocean to become a monopoly in its business. Among the various steps to be followed in planning include individually or jointly analysing the institutional strengths, weaknesses, opportunities, and challenges, identifying the problems in transforming the organization into a highly productive organization in contribution, utilizing right resources in all positions to fuel the objectives and developing a clear policy. Planning should also involve allocation of financial resources to promote various task centres, task groups, task projects, and financial support for various activities related to enhancing organizational output.

(2) Target Setting:

Target setting includes setting the volume of the result to be achieved in a time bound manner for the organization, for its various divisions, groups, and individuals. Target can be set for the entire number 
of employees individually in the organization, namely activity target or result to be created jointly namely output target. Based on the broad institutional policy, the targets could be fixed for quarterly, half yearly, annually and so on. Such target should be communicated to everyone in the organization. This stimulates a process of mutual consultation and dialogue. As a result, the members realize their challenge and learn to redefine their individual and group goal. The target setting for individuals and groups makes everybody prepare and devote their effort towards better performance.

\section{(3) Motivation:}

The basic intention of motivation in Theory A is to help members to discover their own potential through self-exploration. Once the target for the optimum result is set, the organizational leaders/managers should develop and implement various policies to support to meet the targets. Motivation may include support to identify weaknesses, encouragement to come at par with others, appreciation of fair performance, encouragement for collaborative approaches, developing task-based strategies, opportunity for advancement of better performers etc.

\section{(4) Work Strategies:}

Strategy is important for success. First and foremost, it is important that the members of the organization set their individual goals in consonance with the organizational goal. This comes in the form of a desire. A time-frame plan is essential for individuals and groups to accomplish their target. Teamwork through collaborating with other people, and working on more than one sub-activities simultaneously is another strategy. Redefining the target based on successive fulfilment and getting organizational support to fulfil the target is an enabling strategy.

\section{(5) Responsibility:}

This is the major component of both individual and organizational success. When the members show their responsibility towards fulfilling the organizational objective which is enhancing the productivity through increased contribution, no other influencing factors are required for maintaining consistency. But based on personality type, only a few people take responsibility by themselves in any organization. For others, an external stimulus is required to point out their responsibilities. Such stimuli may be helping to set the target, motivation, continuous follow-up, showcasing role model or providing encouragement.

\section{(6) Role Model:}

Role models can be anyone in the organization who outperform and contribute highest to the organization. Irrespective of age, gender, position and any kind of administrative responsibilities, role models can inspire all members of the organization and demonstrate that higher productivity is possible despite constraints. By appreciating and showcasing output of role models, organizations can work on improved targets. Super performers can be the inspiration for everyone in the organization.

\section{(7) Monitoring \& Guiding:}

Once the process is set in motion, continuous monitoring of the process and accelerating productivity is essential in the organization. This will automatically create responsibility and avoid redundancy. Monitoring includes both self-monitoring and monitoring by superiors. This will ensure coping with difficulties and getting on well. Increased confidence will keep the team together. Sharing of result will improve self-esteem. Overall there will be a new work culture of freedom to suggest, delegate, and dependence.

\section{(8) Accountability:}

Accountability should be fixed to everybody including the heads of the departments and director of the organization so that satisfaction can be maintained throughout the organization. The ultimate outcome of this model of organizational operational strategy visualized through different perspectives of six thinking styles. Consistency in performance is the individual ultimate while organizational leaders get preoccupied with managing change. Depending on organizational policy, the accountability may bring positive or negative for achievers or losers respectively.

\section{INTEGRATING THEORY A AND SIX THINKING HATS :}

The different approaches in the lateral thinking process using six thinking hats can be integrated into the various stages of theory A. This results in distinguishing different perspectives from both 
individual and organizational point of view.

\section{1: Theory A using White Thinking Hat :}

White hat stands for quantitative and neutral judgement. Characteristic of this planning is based on facts and figures. Emphasis is on measurable efforts and measurable performance. Institutional need assessment and problem identification arises from perception of self favouring information flow. Adoption of the idea which is the key motivator is visible through enhanced interest and inspiration for result. Role models are judged on acceptable standards of output. Cross checking and verification are employed for monitoring. Accountability is measured through contribution for target realization. The results are depicted in Table 1.

Table 1 : Perspective of White Thinking hat

\begin{tabular}{|l|l|l|l|}
\hline $\begin{array}{l}\text { S. } \\
\text { No. }\end{array}$ & Stages of Theory A & $\begin{array}{l}\text { Organizational/Team Point of } \\
\text { view }\end{array}$ & Individual Point of view \\
\hline 1 & Planning & Realization of facts & Perception of Self \\
\hline 2 & Target Setting & Conception of task & Information flow \\
\hline 3 & Developing Motivation & Inspiration for Results & Enhanced Interest \\
\hline 4 & Devising Work strategies & Measurable of effort & Value for contribution \\
\hline 5 & Creating Responsibility & Measurable performance & Action orientation \\
\hline 6 & Providing Role Model & Acceptable standards & Output orientation \\
\hline 7 & Monitoring and Guiding & Cross checking & Verification \\
\hline 8 & $\begin{array}{l}\text { Developing } \\
\text { Accountability }\end{array}$ & Target realization & Personal satisfaction \\
\hline
\end{tabular}

\subsection{Theory A using Red Thinking Hat:}

The red hat perspective reflects concern for each other with integration as a cause binding them. A humanitarian view is a key consideration in target setting both for results and consequences. The teamwork together with a feeling of involvement helps devising strategy acceptable to everybody. Responsibility intensifies the feeling of integration and role model provides discovery of inner drive. Results are mutually appreciated thereby contributing to attachment to objectives for continued performance. The results are depicted in Table 2.

Table 2 : Perspective of Red Thinking hat

\begin{tabular}{|l|l|l|l|}
\hline $\begin{array}{l}\text { S. } \\
\text { No. }\end{array}$ & $\begin{array}{l}\text { Stages of Theory } \\
\text { A }\end{array}$ & $\begin{array}{l}\text { Organizational/ Team Point of } \\
\text { view }\end{array}$ & Individual Point of view \\
\hline 1 & Planning & Integration of cause & Expression of concerns \\
\hline 2 & Target Setting & Consideration of consequences & Concern for result \\
\hline 3 & $\begin{array}{l}\text { Developing } \\
\text { Motivation }\end{array}$ & Working together & Feeling of involvement \\
\hline 4 & $\begin{array}{l}\text { Devising Work } \\
\text { strategies }\end{array}$ & Solutions suiting everybody & Responding to needs \\
\hline 5 & $\begin{array}{l}\text { Creating } \\
\text { Responsibility }\end{array}$ & Feeling of integration & Shared results \\
\hline 6 & $\begin{array}{l}\text { Providing Role } \\
\text { Model }\end{array}$ & Discovering inner drive & Imitation \\
\hline 7 & $\begin{array}{l}\text { Monitoring and } \\
\text { Guiding }\end{array}$ & Mutual Appreciation & Personal Satisfaction \\
\hline 8 & $\begin{array}{l}\text { Developing } \\
\text { Accountability }\end{array}$ & Continued performance & Attachment to objectives \\
\hline
\end{tabular}

\subsection{Theory A using Yellow Thinking Hat :}

The perspective of the yellow hat is positive and optimistic. Institutional assessment and the problem identification takes care of the strengths thereby a sense of team spirit prevail in joint policy formulation. Shared understanding of common cause brings to focus better alternatives depending on individual perception of consequences. Motivation is vested in maximising returns and appropriate strategy is adopted for empowerment and support. Accountability brings personal rejoice with a feeling of honouring promises. The results are depicted in Table 3. 
Table 3 : Perspective of Yellow Thinking hat

\begin{tabular}{|l|l|l|l|}
\hline S. No. & $\begin{array}{l}\text { Stages of Theory } \\
\text { A }\end{array}$ & $\begin{array}{l}\text { Organizational/Team Point of } \\
\text { view }\end{array}$ & Individual Point of view \\
\hline 1 & Planning & Team spirit & Awareness of strength \\
\hline 2 & Target Setting & Better alternatives & Search for consequences \\
\hline 3 & $\begin{array}{l}\text { Developing } \\
\text { Motivation }\end{array}$ & Maximizing returns & Optimum returns \\
\hline 4 & $\begin{array}{l}\text { Devising Work } \\
\text { strategies }\end{array}$ & Selection of choices & Awareness of choices \\
\hline 5 & $\begin{array}{l}\text { Creating } \\
\text { Responsibility }\end{array}$ & Keeping together & Self confidence \\
\hline 6 & $\begin{array}{l}\text { Providing Role } \\
\text { Model }\end{array}$ & Projecting role model & Following role model \\
\hline 7 & $\begin{array}{l}\text { Monitoring and } \\
\text { Guiding }\end{array}$ & Success achieved & Sigh of relief \\
\hline 8 & $\begin{array}{l}\text { Developing } \\
\text { Accountability }\end{array}$ & Promises honoured & Personal rejoice \\
\hline
\end{tabular}

5.4 Theory A using Black Thinking Hat :

The black hat thinking in planning anticipates difficulties arising out of a pessimistic feeling of consciousness of weakness. Though sceptical, target setting is attempted giving a try and idea is adopted based on minimum loss and balancing of benefits. Role model is accepted finding it suitable and responsibility is reflected in coping with difficulties and getting along well. In devising work strategy minimum conditions are fulfilled by means of self imposed rules by members of the team. Eventually, accountability is reflected in output as best of self.

The results are depicted in Table 4.

Table 4 : Perspective of Black Thinking hat

\begin{tabular}{|l|l|l|l|}
\hline S. No. & Stages of Theory A & $\begin{array}{l}\text { Organizational/Team } \\
\text { Point of view }\end{array}$ & Individual Point of view \\
\hline 1 & Planning & Anticipating difficulties & Conscious of weakness \\
\hline 2 & Target Setting & Giving a try & Scepticism \\
\hline 3 & Developing Motivation & Balancing benefits & Minimizing loss \\
\hline 4 & $\begin{array}{l}\text { Devising Work } \\
\text { strategies }\end{array}$ & Minimizing conditions & Self-imposed rules \\
\hline 5 & Creating Responsibility & Getting along well & Coping with difficulties \\
\hline 6 & Providing Role Model & Suitability of role model & Acceptability of role model \\
\hline 7 & Monitoring and Guiding & Agreement kept & Distress free \\
\hline 8 & $\begin{array}{l}\text { Developing } \\
\text { Accountability }\end{array}$ & Expected output & Best of self \\
\hline
\end{tabular}

\subsection{Theory A using Green Thinking Hat :}

Innovative thinking is characterized by the quest for expression and desire for action. It goes out of the box with fascinating views, incorporating new and taking challenge. Responsibility is marked by commitment and consistency through innovative ideas in the form of suggestions. Adoption of the idea gives motivation for accepting challenges. Challenge taking is reckoned as inspiration for task fulfilment. Role model is accepted as alternative ways of performing better. Acknowledging example gives a sense of achievement to the team and serves the monitoring function. Accountability is manifested through faster returns and new insights. The results are depicted in Table 5.

Table 5 : Perspective of Green Thinking hat

\begin{tabular}{|l|l|l|l|}
\hline S. No. & $\begin{array}{l}\text { Stages of Theory } \\
\text { A }\end{array}$ & $\begin{array}{l}\text { Organizational/Team Point of } \\
\text { view }\end{array}$ & Individual Point of view \\
\hline 1 & Planning & Desire for action & Quest for expression \\
\hline 2 & Target Setting & Incorporating new & Fascinating views \\
\hline
\end{tabular}




\begin{tabular}{|l|l|l|l|}
\hline 3 & $\begin{array}{l}\text { Developing } \\
\text { Motivation }\end{array}$ & Challenge taking & Inspiration \\
\hline 4 & $\begin{array}{l}\text { Devising Work } \\
\text { strategies }\end{array}$ & Increased benefits & Better networking \\
\hline 5 & $\begin{array}{l}\text { Creating } \\
\text { Responsibility }\end{array}$ & Suggestions accepted & Freedom to suggest \\
\hline 6 & $\begin{array}{l}\text { Providing Role } \\
\text { Model }\end{array}$ & Discovery of alternative & Search for alternative \\
\hline 7 & $\begin{array}{l}\text { Monitoring and } \\
\text { Guiding }\end{array}$ & Sense of achievement & Contribution welcome \\
\hline 8 & $\begin{array}{l}\text { Developing } \\
\text { Accountability }\end{array}$ & Faster returns & Newer insights \\
\hline
\end{tabular}

\subsection{Theory A using Blue Thinking Hats :}

Managerial thinking relies on forecasting in problem identification and institutional assessment and is forward-looking in policy formulation. This hat is characterised by an inclination to systems and logic in target setting. Motivation requires little persuasion and minimum of supervision. A work culture of delegation and dependence characterize the organization. Every team member is bent on creating a difference. Review and appraisal of accomplishment involve initiating change. Team contributes with a high degree of consistency and the function of accountability involves managing change in a big way. The results are depicted in Table 6.

Table 6 : Perspective of Blue Thinking hat

\begin{tabular}{|l|l|l|l|}
\hline S. No. & Stages of Theory A & $\begin{array}{l}\text { Organizational/Team Point of } \\
\text { view }\end{array}$ & Individual Point of view \\
\hline 1 & Planning & Forecasting & Forward-looking \\
\hline 2 & Target Setting & Based on systems & Inclination to logic \\
\hline 3 & Developing Motivation & Minimum supervision & Little persuasion \\
\hline 4 & $\begin{array}{l}\text { Devising Work } \\
\text { strategies }\end{array}$ & Greater leadership & Increased clarity \\
\hline 5 & Creating Responsibility & Fostering work culture & Delegation and dependence \\
\hline 6 & Providing Role Model & Realization of goal & Modelling high performer \\
\hline 7 & Monitoring and Guiding & Initiating change & Creating difference \\
\hline 8 & $\begin{array}{l}\text { Developing } \\
\text { Accountability }\end{array}$ & Managing change & Maintaining consistency \\
\hline
\end{tabular}

\section{CONCLUSION :}

Theory A focuses on innate human urge for creativity as the basis for individual and organizational performance. This when integrated into the six hats thinking technique in decision making brings out multiple perspectives. These perspectives reveal the characteristic feature of each thinking. The sequence of process of theory A are well established as it emerges from the analysis. This analysis serves as a framework for adopting in application to different problems. Thus, Theory A (Theory of Accountability) though developed as organizational performance theory to fill the gap between $20^{\text {th }}$ century theories and emerging requirements of $21^{\text {st }}$ century we found that it can be a useful framework [37-72] to discuss various perspectives under six thinking hats model of lateral thinking in application to organizations and individuals such as objective and quantitative thinking, emotional and humanistic thinking, negative pessimistic thinking, cautious optimistic thinking, creative innovative thinking and managerial thinking.

\section{REFERENCES :}

[1] Woodman, R. W., Sawyer, J. E., \& Griffin, R. W. (1993). Toward a theory of organizational creativity. Academy of management review, 18(2), 293-321.

[2] Marcoulides, G. A., \& Heck, R. H. (1993). Organizational culture and performance: Proposing 
and testing a model. Organization science, 4(2), 209-225.

[3] Den Hartog, D. N., Boselie, P., \& Paauwe, J. (2004). Performance management: A model and research agenda. Applied psychology, 53(4), 556-569.

[4] Zakuan, N. M., Yusof, S. M., Laosirihongthong, T., \&Shaharoun, A. M. (2010). Proposed relationship of TQM and organisational performance using structured equation modelling. Total Quality Management, 21(2), 185-203.

[5] Rothwell, W.J. (1996), ASTD Models for Human Performance Improvement, ASRD, Alexandria, VA.

[6] Strickland, D. (2000). Emotional intelligence: The most potent factor in the success equation. Journal of nursing administration, 30(3), 112-117.

[7] Murray, B. (1998). Does emotional intelligence matter in the workplace. APA monitor, 29(7), 1-3.

[8] Khalili, A. (2012). The role of emotional intelligence in the workplace: A literature review. International Journal of Management, 29(3), 355-364.

[9] Seal, C. R., \& Andrews-Brown, A. (2010). An integrative model of emotional intelligence: emotional ability as a moderator of the mediated relationship of emotional quotient and emotional competence. Organization Management Journal, 7(2), 143-152.

[10] Riggio, R. E., \& Lee, J. (2007). Emotional and interpersonal competencies and leader development. Human Resource Management Review, 17(4), 418-426.

[11] Ahmed, A., Arshad, M. A., Mahmood, A., \& Akhtar, S. (2016). Spiritual intelligence (SQ): a holistic framework for human resource development. Administratiesi Management Public, (26), 60-68.

[12] Karimi, Z., \&Karimi, F. (2016). The structural model of relationship between spiritual intelligence and emotional intelligence with quality of work life and work engagement of employees. International Journal of Management in Education, 10(3), 278-292.

[13] Sanghi, S. (2016). The handbook of competency mapping: understanding, designing and implementing competency models in organizations. SAGE Publications India.

[14] Anisha, N. (2012). Competency Mapping of the Employees. International Journal of Advancements in Research \& Technology, 1(5), 1-7.

[15] Belsare, M. (2012). The Role Of Competency Mapping In Employee Performance and Development With Respect To Selected IT Industries In Pune City. ASM's International EJournal on Ongoing Research in Management \& IT, 285-293.

[16] Jinadasa, A. N. (2015). Human Potential Development: A New HRD Model for Turbulent Times. China-USA Business Review, 100-108.

[17] Jyoti, J., \& Dev, M. (2016). Perceived High-performance Work System and Employee Performance: Role of Self-efficacy and Learning Orientation. Metamorphosis, 15(2), 115-133.

[18] Deming, D. J. (2017). The growing importance of social skills in the labor market. The Quarterly Journal of Economics, 132(4), 1593-1640.

[19] Singh, R., Singh, R., Chawla, G., Chawla, G., Agarwal, S., Agarwal, S. \& Desai, A. (2017). Employability and innovation: development of a scale. International Journal of Innovation Science, 9(1), 20-37.

[20] Jha, B., \& Kumar, A. (2016). Employee engagement: A strategic tool to enhance performance. DAWN: Journal for Contemporary Research in Management, 3(2), 21-29. 
[21] Borg, S. W., \& Johnston, W. J. (2013). The IPS-EQ model: interpersonal skills and emotional intelligence in a sales process. Journal of Personal Selling \& Sales Management, 33(1), 39-51.

[22] McGregor, D. M. (1960). The human side of enterprise. New York: McGraw-Hill.

[23] Ouchi, W. G., \& Price, R. L., (1978). Hierarchies, clans and theory Z: A new perspective on organization development. Organizational Dynamics, 7(2), 25-44.

[24] Aithal, P. S., \& Suresh Kumar, P. M. (2016). Organizational Behaviour in $21^{\text {st }}$ Century - Theory A for Managing People for Performance. IOSR Journal of Business and Management (IOSRJBM), 18(7), 126-134. DOI: http://doi.org/10.9790/487X-180704126134.

[25 ] Aithal, P. S. (2016). How to Increase Research Productivity in Higher Educational Institutions SIMS Model. International Journal of Scientific Research and Modern Education (IJSRME), 1(1), 447-458. DOI : http://doi.org/10.5281/zenodo.161037.

[26] Aithal, P. S., \& Suresh Kumar, P. M. (2016). Comparative Analysis of Theory X, Theory Y, Theory Z, and Theory A for Managing People and Performance. International Journal of Scientific Research and Modern Education (IJSRME), 1(1), 803-812. DOI: http://doi.org/10.5281/zenodo.154600.

[27] Aithal, P. S. \& Suresh Kumar, P. M. (2016). Theory A for Optimizing Human Productivity, IRAInternational Journal of Management \& Social Sciences, 4(3), 526-535. DOI : http://dx.doi.org/10.21013/jmss.v4.n3.p2.

[28] Aithal, P. S. \& Suresh Kumar, P. M. (2016). CCE Approach through ABCD Analysis of 'Theory A' on Organizational Performance. International Journal of Current Research and Modern Education (IJCRME), 1(2), 169-185. DOI: http://dx.doi.org/10.5281/zenodo.164704.

[29] Aithal, P. S. \& Suresh Kumar P. M. (2017). Interconnecting Theory A and ABC Model of Organizational Performance. International Journal of Management, Technology and Social Sciences (IJMTS), 1(1), 1-13. DOI: http://dx.doi.org/10.5281/zenodo.268598.

[30] De Bono, E. (1999) Six Thinking Hats, Back Bay Books, New York.

[31] Govind Sharma, Six Hats Thinking, its analysis and practically used example, http://blog.simplycareer.net/2013/05/six-hats-thinking-its-analysis-and.html.

[32] Aithal, P. S., Shailashree V. T. \& Suresh Kumar P.M. (2016). Factors \& Elemental Analysis of Six Thinking Hats Technique using ABCD Framework. International Journal of Advanced Trends in Engineering and Technology (IJATET), 1(1), 85-95. DOI: http://doi.org/10.5281/zenodo.240259.

[33] Aithal, P. S. \& Suresh Kumar, P. M. (2016). Using Six Thinking Hats as a Tool for Lateral Thinking in Organizational Problem Solving. International Journal of Engineering Research and Modern Education (IJERME), 1(2), 225-234. DOI: http://dx.doi.org/10.5281/ZENODO.198724.

[34] Aithal, P. S. \& Suresh Kumar, P. M. (2017). Lateral Thinking in Managerial Decision Making Through Six Thinking Hats Technique.International Journal of Scientific Research and Modern Education (IJSRME), 2(1), 53-58. DOI: http://dx.doi.org/10.5281/ZENODO.438149.

[35] Aithal, P. S. \& Suresh Kumar, P. M. (2017). Lateral Thinking in Managerial Decision Making Through Six Thinking Hats Technique.International Journal of Scientific Research and Modern Education (IJSRME), 2(1), 53-58. DOI: http://dx.doi.org/10.5281/ZENODO.438149.

[36] Aithal, P. S., Suresh Kumar P. M. (2017). Ideal Analysis for Decision Making in Critical Situations through Six Thinking Hats Method. International Journal of Applied Engineering and Management Letters (IJAEML), 1(2), 1-9. DOI: http://dx.doi.org/10.5281/zenodo.838378.

[37] Aithal, P. S., (2016). Study on ABCD Analysis Technique for Business Models, Business Strategies, Operating Concepts \& Business Systems. International Journal in Management and 
Social Science, 4(1), 98-115. DOI : http://doi.org/10.5281/zenodo.161137.

[38] Aithal, P. S., Shailashree, V. T., \& Suresh Kumar, P. M. (2015). Application of ABCD Analysis Model for Black Ocean Strategy. International Journal of Applied Research (IJAR), 1(10), 331337. DOI: http://doi.org/ 10.5281/zenodo.163424.

[39] Aithal, P. S., Shailashree, V. T., \& Suresh Kumar, P. M. (2016). ABCD analysis of Stage Model in Higher Education. International Journal of Management, IT and Engineering (IJMIE), 6(1), 11-24. DOI: http://doi.org/10.5 281/zenodo.154233.

[40] Aithal, P. S., Shailashree, V.T., \& Suresh Kumar, P. M. (2016). Analysis of NAAC Accreditation System using ABCD framework. International Journal of Management, IT and Engineering (IJMIE), 6(1), 30 - 44. DOI: http://doi.org/10.5281/zenodo.154272.

[41] Aithal, P. S., Shailashree, V. T., \& Suresh Kumar, P. M. (2016). Application of ABCD Analysis Framework on Private University System in India. International Journal of Management Sciences and Business Research (IJMSBR), 5(4), 159-170. DOI : http://doi.org/10.5281/zenodo.161111.

[42] Aithal, P. S., Shailashree, V. T., \& Suresh Kumar, P. M., (2016). The Study of New National Institutional Ranking System using ABCD Framework. International Journal of Current Research and Modern Education (IJCRME), 1(1), 389 - 402. DOI : http://doi.org/10.5281/zenodo.161077.

[43] Aithal, P. S., Shailashree, V. T. \& Suresh Kumar, P. M., (2016). Analysis of ABC Model of Annual Research Productivity using ABCD Framework. International Journal of Current Research and Modern Education (IJCRME), 1(1), 846-858. DOI : http://doi.org/10.5281/ zenodo.62022.

[44] ShubhrajyotsnaAithal, \& Aithal, P. S., (2016), ABCD analysis of Dye doped Polymers for Photonic Applications. IRA-International Journal of Applied Sciences, 4(3), 358-378. DOI:http://dx.doi.org/10.21013/jas.v4.n3.p1.

[45] Aithal, P. S. \& Suresh Kumar, P. M. (2016). CCE Approach through ABCD Analysis of 'Theory A' on Organizational Performance. International Journal of Current Research and Modern Education (IJCRME) 1(1), 169-185. DOI: http://dx.doi.org/10. 5281/zenodo.164704.

[46] Varun Shenoy, \& Aithal P. S., (2016). ABCD Analysis of On-line Campus Placement Model, IRA-International Journal of Management \& Social Sciences, 5(2), 227-244. DOI: http://dx.doi.org/10.21013/jmss.v5.n2.p3.

[47] Aithal, P. S., Shailashree V. T. \& Suresh Kumar P. M. (2016). Factors \& Elemental Analysis of Six Thinking Hats Technique using ABCD Framework. International Journal of Advanced Trends in Engineering and Technology (IJATET), 1(1), 85-95. DOI : http://doi.org/10.5281/zenodo.240259.

[48] Aithal, P. S. (2017). ABCD Analysis of Recently Announced New Research Indices. International Journal of Management, Technology, and Social Sciences (IJMTS), 2(1), 65-76. DOI: http://doi.org/10.5281/zenodo. 583644.

[49] Aithal, P. S. (2017). Factor Analysis based on ABCD Framework on Recently Announced New Research Indices, International Journal of Management, Technology, and Social Sciences (IJMTS), 1(1), 82-94. DOI: http://dx.doi.org/10.5281/zenodo.584105.

[50] Aithal, P. S., Shailashree, V. T., Suresh Kumar, P. M. (2015). A New ABCD Technique to Analyze Business Models \& Concepts. International Journal of Management, IT and Engineering (IJMIE), 5(4), 409 - 423. DOI : http://doi.org/10.5281/zenodo.61652.

[51] Aithal, P. S., (2017).ABCD Analysis as Research Methodology in Company Case Studies. International Journal of Management, Technology, and Social Sciences (IJMTS), 2(2), 40-54. 
DOI: http://dx.doi.org/10.5281/zenodo.891621.

[52] Aithal, P. S. (2016). Review on Various Ideal System Models Used to Improve the Characteristics of Practical Systems. International Journal of Applied and Advanced Scientific Research, 1(1), 47-56. DOI : http://doi.org/10.5281/zenodo.159749.

[53] Aithal, P. S. (2016). Ideal Banking Concept and Characteristics. International Research Journal of Management, IT and Social Sciences (IRJMIS), 3(11), 46-55. DOI : http://dx.doi.org/10.21744/irjmis.v3i11.311.

[54] Aithal, P. S. and Vaikuth Pai, T. (2016). Concept of Ideal Software and its Realization Scenarios, International Journal of Scientific Research and Modern Education (IJSRME), 1(1), 26-837. DOI : http://doi.org/10.5281/zenodo.160908.

[55] Aithal, P. S. (2016). A Comparison of Ideal Banking Model with Mobile Banking System. International Journal of Current Research and Modern Education (IJCRME), 1(2), 206-224. DOI: http://dx.doi.org/10.5281/ZENODO.198708.

[56] Krishna Prasad, K., Aithal, P. S. (2017). A Customized and Flexible Ideal Mobile Banking System using 5G Technology. International Journal of Management, Technology, and Social Sciences (IJMTS), 2(1), 25-37. DOI: http://dx.doi.org/10.5281/zenodo.820860.

[57] Sridhar Acharya, P. and Aithal, P. S. (2016). Concepts of Ideal Electric Energy System for production, distribution and utilization, International Journal of Management, IT and Engineering (IJMIE), 6(1), 367-379, DOI : http://doi.org/10.5281/zenodo.161143.

[58] Aithal, P. S. (2016). The concept of Ideal Strategy \& its realization using White Ocean Mixed Strategy, International Journal of Management Sciences and Business Research (IJMSBR), 5(4), 171-179. DOI : http://doi.org/10.5281/zenodo.161108.

[59] Aithal, P.S. (2016). Realization of Ideal Banking Concept using Ubiquitous Banking, International Journal of Scientific Research and Modern Education (IJSRME), 1(2), 119-135. DOI: http://dx.doi.org/10.5281/ZENODO.164703

[60] Shubrajyotsna Aithal, \& Aithal, P. S., Bhat, G. K. (2016). Characteristics of Ideal Optical Limiter and Realization Scenarios using Nonlinear Organic Materials - A Review. International Journal of Advanced Trends in Engineering and Technology (IJATET), 1(1), 73-84. DOI : http://doi.org/10.5281/zenodo.240254.

[61] Aithal, P. S., \& Shubhrajyotsna Aithal, (2015). Ideal Technology Concept \& its Realization Opportunity using Nanotechnology, International Journal of Application or Innovation in Engineering \& Management (IJAIEM), 4(2), $153 \quad-\quad 164$, DOI: http://doi.org/10.5281/zenodo.61591.

[62] Aithal, P. S. (2015). Concept of Ideal Business \& Its Realization using E-Business Model. International Journal of Science and Research (IJSR), 4(3), 1267 - 1274. DOI : http://doi.org/10.5281/zenodo.61648.

[63] Aithal, P. S. (2015). Mobile Business as an Optimum Model for Ideal Business. International Journal of Management, IT and Engineering (IJMIE), 5(7), 146-159. DOI : http://doi.org/10.5281/zenodo.163880.

[64] Aithal, P. S. \& Shubhrajyotsna Aithal, (2015). An Innovative Education Model to realize Ideal Education System. International Journal of Scientific Research and Management (IJSRM), 3(3), 2464 - 2469. DOI: http://doi.org/10.5281/zenodo.61654.

[65] Aithal, P. S. \& Suresh Kumar, P.M., (2016). ABC Model of Research Productivity and Higher Educational Institutional Ranking, International Journal of Education and Management Engineering (IJEME), 6(6), 74-84. DOI: http://doi.org/10.5815/ijeme.2016.06.08. 
[66] Aithal, P. S. (2016). Study of Annual Research Productivity in Indian Top Business Schools. International Journal of Scientific Research and Modern Education (IJSRME), 1(1), 402-414. DOI : http://doi.org/10.5281/zenodo.161041.

[67] Aithal, P. S. (2016). Study of Research Productivity in World Top Business Schools, International Journal of Engineering Research and Modern Education (IJERME), 1(1), 629-644, DOI : http://doi.org/10.5281/zenodo.160969.

[68] Aithal, P. S., Shailashree V. T\& Suresh Kumar P. M., (2016). Analysis of ABC Model of Annual Research Productivity using ABCD Framework. International Journal of Current Research and Modern Education (IJCRME), 1(1), 846-858.

DOI : http://doi.org/10.5281/zenodo.62022.

[69] Aithal, P. S. (2016). Research Performance Analysis of Some Indian Top Business Schools Using ABC Model. International Journal of Computational Research and Development, 1(1), 70-83. DOI :http://doi.org/10.5281/zenodo.163532.

[70] Aithal, P. S., (2016). Inspiring through Self-Contribution - An Analysis of How Active the Indian Top Business School Directors in Research \& Publications. International Journal of Engineering Research and Modern Education (IJERME),1(2), 137 - 154. DOI: http://dx.doi.org/ 10.5281/zenodo.164690.

[71] Aithal, P. S., (2016). Excellence in Individual Research \& Publications : Examining the Active Role of Role models (Deans) of World Top Business Schools. International Journal of Engineering Research and Modern Education (IJERME), 1(2), 179-199. DOI: http://dx.doi.org/ 10.5281/zenodo.192881.

[72] Aithal, P. S. \& Suresh Kumar P. M., (2016). ABC Model of Research Productivity and Higher Educational Institutional Ranking, Proceedings of National conference on Curriculum Design and Development for Student centric Learning, pages 11-22, ISBN 978-81-929306-9-5. 